\title{
The synthesis of 1,2,3,4-tetrahydro-2,2-dimethylquinolin-4-ones as antioxidant precursors
}

\author{
Ian Phillip Clarke and Otto Meth-Cohn* \\ Chemistry Department, Sunderland University, Sunderland SR1 3SD, UK \\ E-mail: otto.meth-cohn@sunderland.ac.uk
}

Dedicated to Gurnos Jones on his seventieth birthday

(receive 10d Feb 00; accepted 13 Feb 00; published on the web 21 Feb 00)

\begin{abstract}
Several routes to the title compounds were explored; a) from 4-ethoxy-quinaldine-1-oxide and methylmagnesium iodide; b) from 3,3-dimethylacrylic acid, 3-chloro-3-methylbutyric acid or 3amino-3-methylbutyric acid and appropriate anilines or activated fluorobenzenes and c) from 2,2-dimethyl-1,2,3,4-tetrahydroquinolines by Boc protection, $\mathrm{BH}_{3} / \mathrm{H}_{2} \mathrm{O}_{2}$ mediated 4hydroxylation and oxidation. The last process proved optimal, but nitroxides of the products were insufficiently stable to be isolated.
\end{abstract}

Keywords: Tetrahydro-2,2-dimethylquinolin-4-one synthesis, tetrahydroquinolines, Boc protection, hydrogen peroxide, hydroxylation

\section{Introduction}

Nitroxides are commercially important as antioxidants, the most common being derived from sterically hindered piperidines such as 2,2,6,6-tetramethylpiperidine, discovered by Russian chemists. ${ }^{1}$ 4-Substituted analogues such as the 4-one derivatives proved particularly useful. Although some examples of the corresponding 2,2-dimethyltetrahydroquinoline precursors are also known ${ }^{2}$ and some are of commercial importance, only one report of the synthesis of the title system had been described at the start of this work, ${ }^{3}$ but the method proved long and not easily reproduced. We herein have investigated a variety of routes and defined the optimal approach to such systems. This literature route is shown in Scheme 1, commencing with the propargylation of aniline, alkyne chlorination of the product, Claisen-type rearrangement of this intermediate and subsequent cyclisation and functional manipulation. We were unable to reproduce the key chlorination step. Indeed, attempts to follow the literature purification of this product were decidedly hazardous, the chloroalkyne undergoing exothermic decomposition, while utilisation 
of the unpurified product proved unsuccessful. We have therefore studied alternative approaches to this product and to other analogues thereof.

\section{Results and Discussion}

Method 1 - via 2-methyl-4-ethoxyquinoline-1-oxide. Eberson and co-workers ${ }^{4}$ have shown that 2-phenyl-4-ethoxyquinoline-1-oxide reacts with Grignard reagents at the 2-position, allowing subsequent ready conversion into 2,2-disubstituted 1,2,3,4-tetrahydroquinol-4-ones. We therefore attempted the same reaction commencing with 4-ethoxyquinaldine-1-oxide, readily made from the parent quinoline with sodium perborate, ${ }^{5}$ under the described conditions (Scheme 2). Unfortunately this lead solely to oxidative deoxygenation of the $\mathrm{N}$-oxide.

Method 2 - From 3,3-dimethylacrylic acid and anilines and related methods. 1,2,3,4Tetrahydro-4-quinolones have been prepared by cyclisation of 3-anilinopropionic acids with PPA, ${ }^{6}$ and the same conditions allow conversion of $p$-cresol and 3,3-dimethylacrylic acid, into a 2,2,6-trimethylchroman-4-one. ${ }^{6}$ The reaction did not proceed when aniline replaced $p$-cresol, no doubt due to N-protonation of the aniline. Heating the reagents together in the absence of PPA gave the corresponding dimethylacrylanilide rather than addition to the double bond. Using benzylamine in place of aniline is reported to result in the addition to the $\mathrm{C}=\mathrm{C}{ }^{7}$

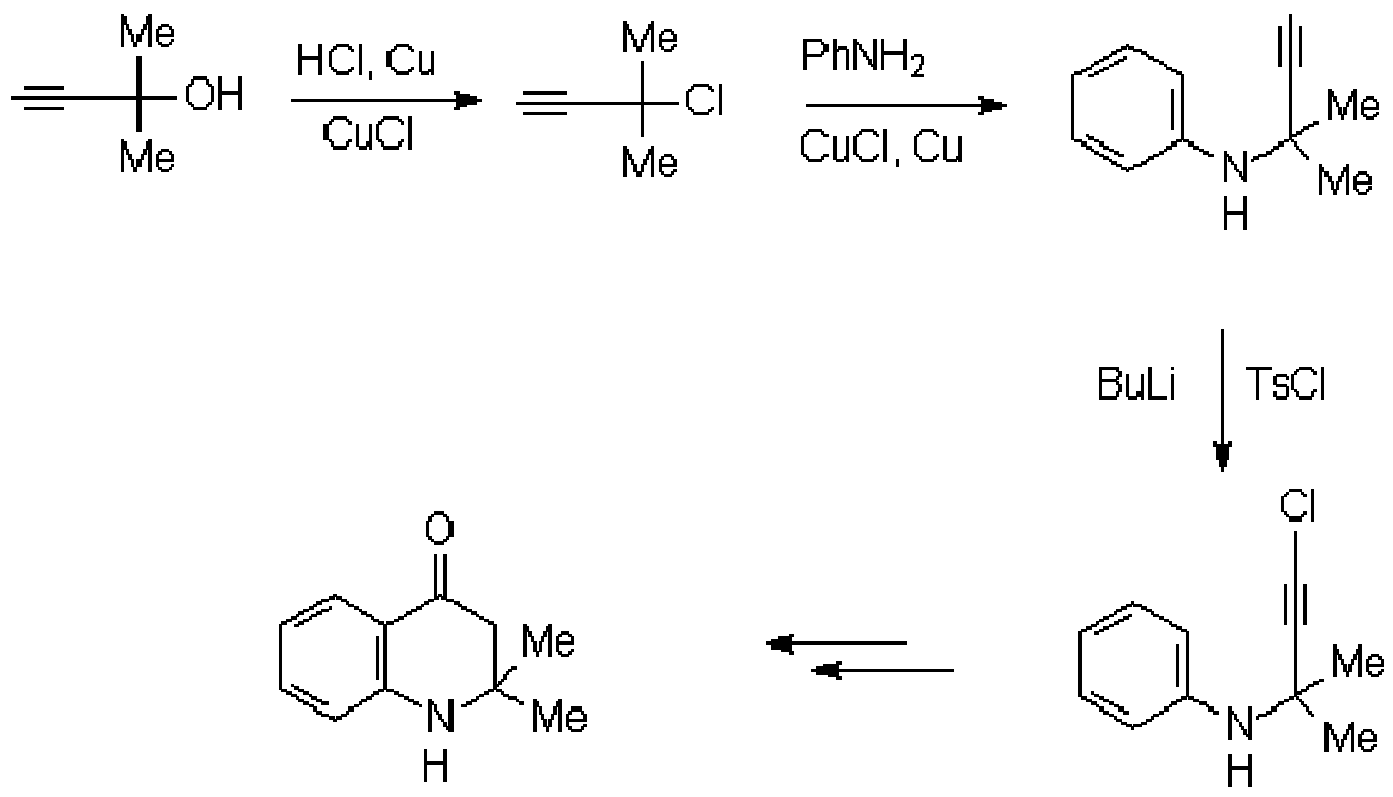

\section{Scheme 1}




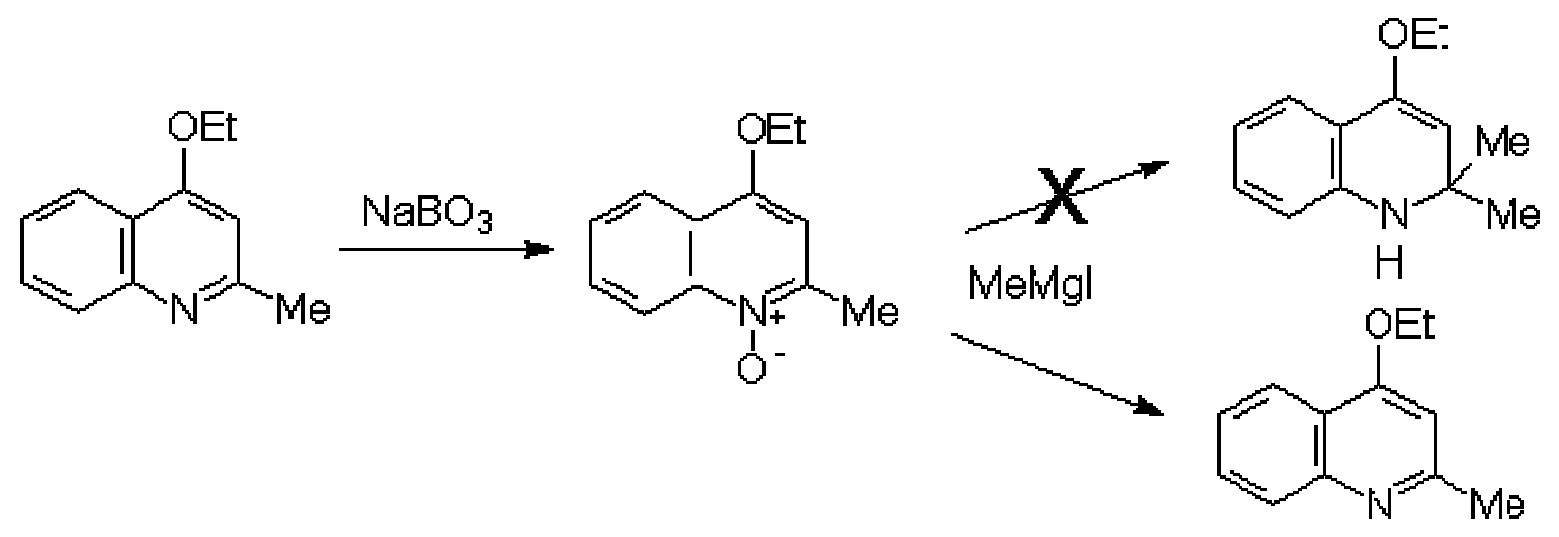

Scheme 2

As a variant on this approach we also examined the interaction of 3-chloro-3-methylbutyric acid with aniline.The chloroacid has been reported, made by either addition of $\mathrm{HCl}$ to the dimethylacrylic acid, ${ }^{8}$ (a reaction we were not able to reproduce) or by the free radical chlorination of 3-methylbutyric acid using sufuryl chloride / benzoyl peroxide. ${ }^{9}$ NMR examination of the product of halogenation showed that the supposed 3-chloro-derivative was in fact the 4-chloro-3-methylbutyric acid. In fact, terminal chlorination is known to be preferred under radical conditions for propionic, isobutyric and butyric acids, due to the inductive effect of the carboxyl moiety. ${ }^{10}$

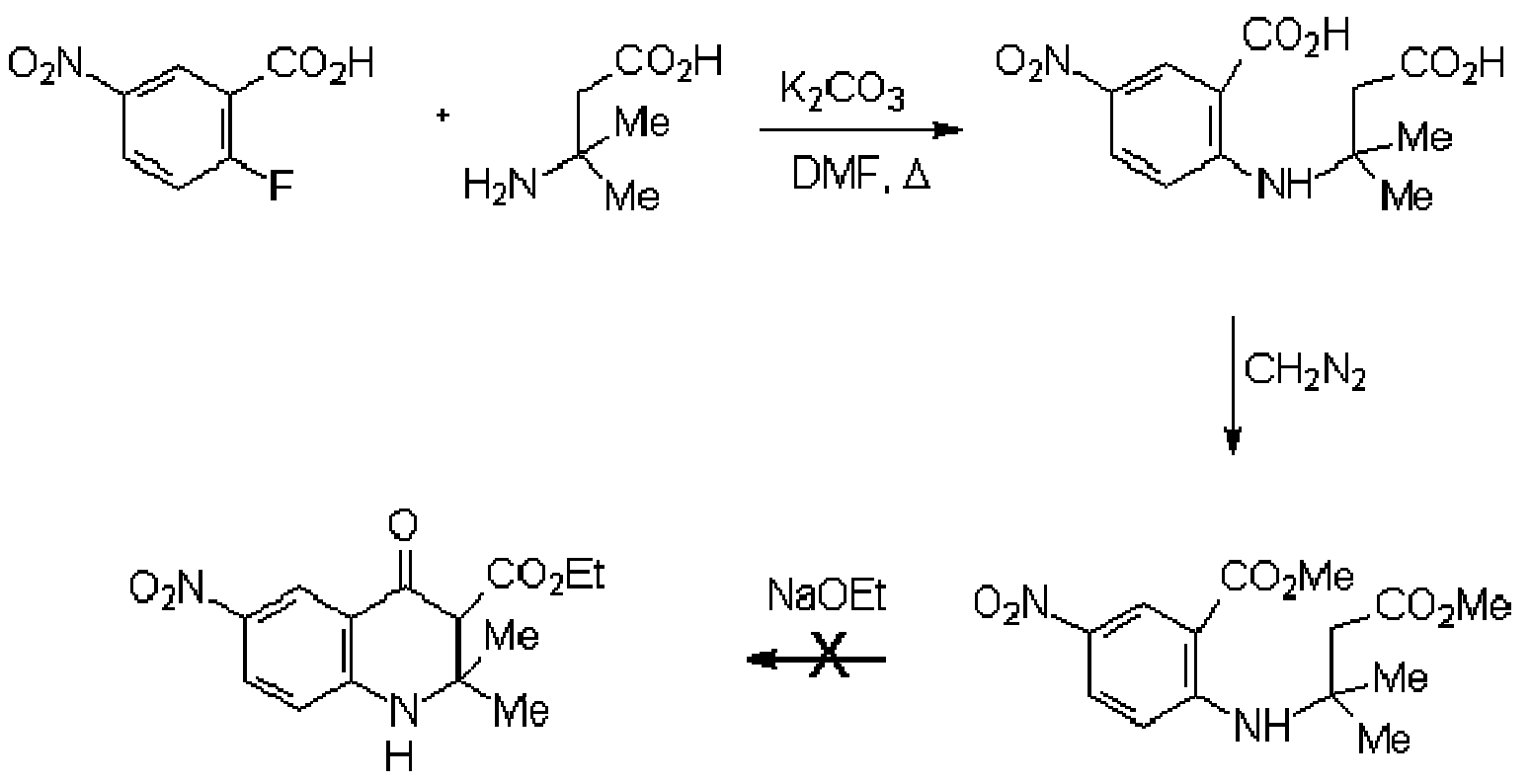

\section{Scheme 3}


Another variant on this approach involved the reaction of 3-amino-3-methylbutyric acid with an activated halobenzene, by nucleophilic substitution of the halogen. Our first attempt utilised 2-fluorobenzoic acid, which proved insufficiently reactive, and therefore 2-fluoro-5-nitrobenzoic acid was employed. The desired substitution proceeded efficiently (Scheme 3), and the diacid was esterified, but an attempted Claisen condensation of the diester failed.

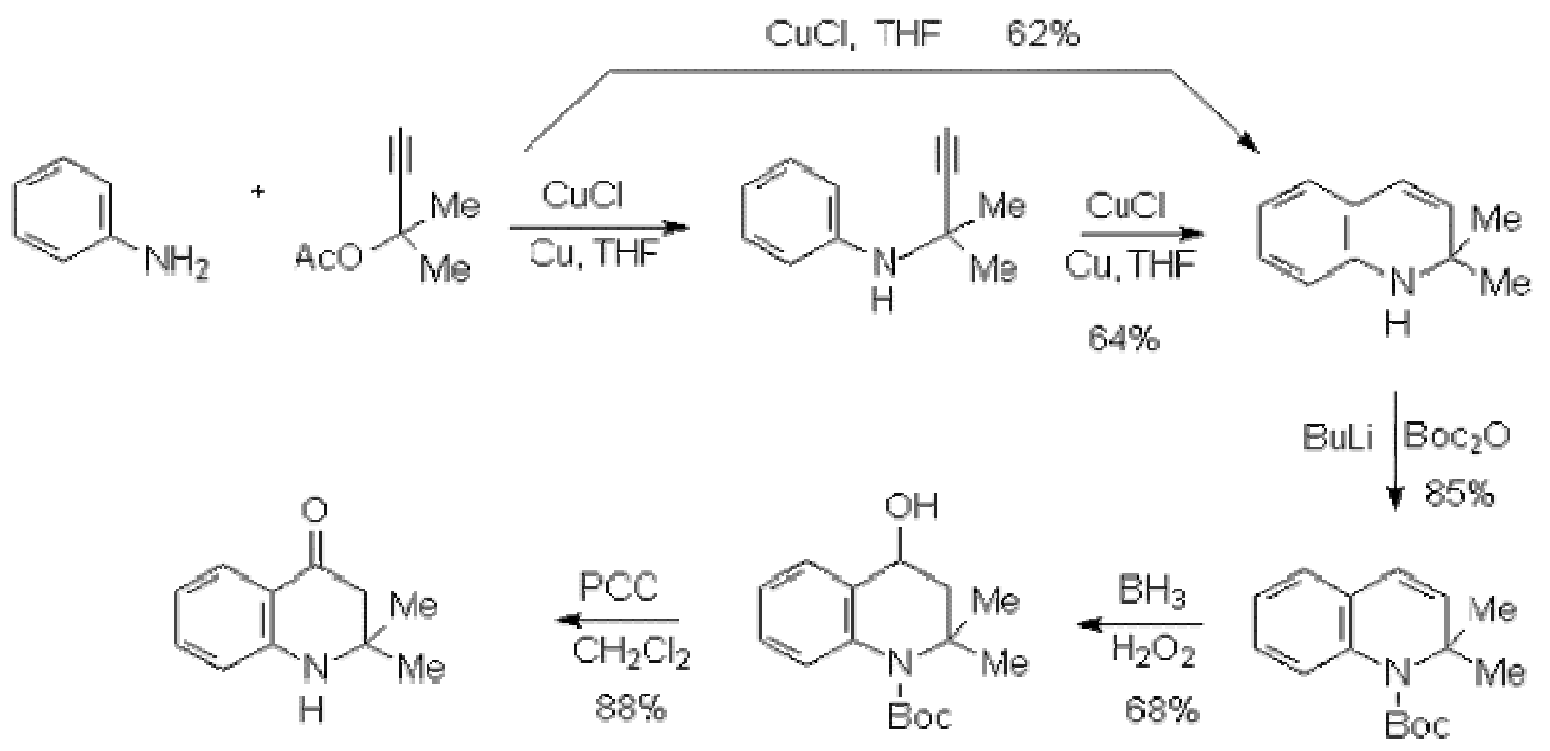

\section{Scheme 4}

Method 3 - From 2,2-dimethyl-1,2-dihydroquinolines. While we were undertaking this study, a pharmaceutical group published a synthesis of the Boc derivative of our desired 2,2-dimethyltetrahydroquinolin-4-one, by way of the title dihydroquinolines (Scheme 4). ${ }^{11}$ The intermediate dihydroquinoline in our hands was available in one step directly from aniline in $62 \%$ yield by a slight increase in the amount of $\mathrm{CuCl}$ catalyst, obviating the hazardous purification of the unstable propargylated intermediate. The Boc protection of the dihydroquinoline is essential in order to ensure $\mathrm{BH}_{3}$ addition at the 4-position, and the subsequent conversion into the 4-ol. Although we found that the protection was hard to drive to completion, the downstream oxidation, purification and deprotection proved non-problematic. The reaction was also successfully repeated with 2-methylaniline to give the more crowded 2,2,8-trimethyl-1,2,3,4tetrahydroquinolin-4-one, potentially a better antioxidant precursor.

It is of interest to report that all attempts to generate a stable nitroxide derivative from these two quinolines using sodium tungstate ${ }^{12}$ or dimethyldioxirane were without success. Although some evidence of nitroxide formation was adduced, they both proved very unstable. 


\section{Experimental Section}

General Procedures. Melting points were conducted on a Reichert Kofler hot-stage apparatus, infrared specra recorded on a Unicam Research Series 1 FTIR as liquid films or KBr discs, NMR spectra in $\mathrm{CDCl}_{3}$ using TMS as internal standard on a JEOL GSX $270 \mathrm{MHz}$ instrument and mass spectra on a Kratos MS80RF or a VG Trio 2000 instrument. Microanalyses were performed on a Carlo Erba 1106 Elemental Analyser at Newcastle University. TLC on Merck silica gel $60 \mathrm{~F}_{254}$ plates and flash chromatography on Janssen silica $(35-70 \mathrm{~mm})$ or Fluka silica $(40-63 \mathrm{~mm})$. Light petroleum refers to that of b.p. $60-80{ }^{\circ} \mathrm{C}$. The following compounds were made according to the literature: 3-Chloro-3-methylbut-1-yne, ${ }^{13}$ 3-anilino-3-methylbut-1-yne, ${ }^{3}$ 4-ethoxy-2methylquinol-ine-1-oxide, ${ }^{14}$ B-aminoisovaleric acid, ${ }^{15}$ 2-fluoro-5-nitrobenzoic acid, ${ }^{16} 3$-acetoxy3-methylbut-1-yne. ${ }^{11}$

Attempted synthesis of 1-chloro-3-anilino-3-methylbut-1-yne. ${ }^{3}$ To a solution of 3-anilin-3methylbut-1-yne $(2.56 \mathrm{~g}, 16.11 \mathrm{mmol})$ in dry THF $(60 \mathrm{~mL})$ at $-60{ }^{\circ} \mathrm{C}$ was added a solution of $n$ $\operatorname{BuLi}(2.5 \mathrm{M}, 18 \mathrm{~mL}, 45 \mathrm{mmol})$ in hexanes over $5 \mathrm{~min}$. The reaction mixture was stirred at the same temperature for $10 \mathrm{~min}$ and then a solution of tosyl chloride $(3.69 \mathrm{~g}, 19 \mathrm{mmol})$ in dry THF $(30 \mathrm{~mL})$ added over $5 \mathrm{~min}$. The reaction mixture was stirred for $2 \mathrm{~h}$, during which time the mixture warmed to ambient. The solution was poured into water $(30 \mathrm{~mL})$ and concentrated under reduced pressure. The residue was extracted with ether $(3 \times 20 \mathrm{~mL})$, dried $\left(\mathrm{K}_{2} \mathrm{CO}_{3}\right)$ and concentrated under reduced pressure. Attempted distillation at $100{ }^{\circ} \mathrm{C} / 0.1 \mathrm{mmHg}$ of the residual oil caused exothermic decomposition and yielded a black tar that could not be identified.

Attempted synthesis of 1,2,3,4-tetrahydro-2,2-dimethylquinolin-4-one. To a mixture of 4ethoxy-2-methylquinoline-1-oxide $(0.25 \mathrm{~g}, 1 \mathrm{mmol})$ in dry THF $(10 \mathrm{~mL})$ at room temperature was added an ethereal solution of methylmagnesium iodide $(3 \mathrm{M}, 1.5 \mathrm{~mL})$ over $5 \mathrm{~min}$. The reaction mixture was stirred for $1 \mathrm{~h}$ then poured into aqueous $\mathrm{NH}_{4} \mathrm{Cl}(10 \%, 35 \mathrm{~mL})$ and extracted with chloroform $(3 \times 30 \mathrm{~mL})$. The extracts were dried $\left(\mathrm{MgSO}_{4}\right)$ and concentrated under reduced pressure. To a solution of the residue in glacial acetic acid $(5 \mathrm{~mL})$ was added iron filings $(0.25 \mathrm{~g}, 4 \mathrm{mmol})$ and the mixture stirred at reflux for $1 \mathrm{~min}$. The mixture was cooled, diluted with acetone $(15 \mathrm{~mL})$ and filtered. The filtrate was concentrated under reduced pressure, basified with aqueous $\mathrm{NaHCO}_{3}$ and extracted with chloroform $(3 \times 30 \mathrm{~mL})$. The extracts were dried $\left(\mathrm{MgSO}_{4}\right)$ and concentrated under reduced pressure. Chromatography using ethyl acetate - light petroleum (1:9) as the eluent yielded 4-ethoxy-2-methylquinoline $(0.15 \mathrm{~g}, 64 \%)$ as a yellow oil (lit. ${ }^{17}$ m.p. $\left.41-43.5{ }^{\circ} \mathrm{C}\right) ;{ }^{1} \mathrm{HNMR} \delta 1.52\left(3 \mathrm{H}, \mathrm{td}, J=7.25,6.60 \mathrm{~Hz}, \mathrm{CH}_{3}\right), 2.68\left(3 \mathrm{H}, \mathrm{s}, \mathrm{CH}_{3}\right), 4.18$ $\left(2 \mathrm{H}, \mathrm{dd}, J=7.26,6.60 \mathrm{~Hz}, \mathrm{CH}_{2}\right), 6.58(1 \mathrm{H}, \mathrm{s}, \mathrm{ArH}), 7.36(1 \mathrm{H}, \mathrm{t}, J=8.58 \mathrm{~Hz}, \mathrm{ArH}), 7.57(1 \mathrm{H}, \mathrm{t}$, $J=8.58 \mathrm{~Hz}, \mathrm{ArH}), 7.90(1 \mathrm{H}, \mathrm{d}, J=7.92 \mathrm{~Hz}, \mathrm{ArH}), 8.09(1 \mathrm{H}, \mathrm{d}, J=7.91 \mathrm{~Hz}, \mathrm{ArH})$.

Reaction of aniline with 3,3-dimethylacrylic acid in PPA . A mixture of 3,3-dimethylacrylic acid $(10 \mathrm{~g}, 0.1 \mathrm{~mol})$, aniline $(9.3 \mathrm{~g}, 0.1 \mathrm{~mol})$ and PPA $(20 \mathrm{~mL})$ was stirred at $85{ }^{\circ} \mathrm{C}$ for $20 \mathrm{~h}$. After a water quench and extraction with dichloromethane, TLC using light petroleum - ethyl 
acetate (3:7) showed no reaction had occurred. The temperature was increased to $120{ }^{\circ} \mathrm{C}$ for $12 \mathrm{~h}$ and still showed no reaction.

Reaction of aniline with 3,3-dimethylacrylic acid . A mixture of 3,3-dimethylacrylic acid (5.03 g, $50 \mathrm{mmol}$ ) and aniline $(5.57 \mathrm{~g}, 60 \mathrm{mmol})$ was stirred at reflux for $7 \mathrm{~h}$. After cooling, the aniline was removed by steam distillation and the residue extracted with chloroform ( $3 \times 30 \mathrm{~mL})$. The combined extracts were dried $\left(\mathrm{MgSO}_{4}\right)$ and concentrated under reduced pressure. Chromatography with ethyl acetate - light petroleum ether $(3: 7)$ as the eluent yielded N-phenyl3,3-dimethylacrylamide $(0.276 \mathrm{~g}, 3 \%)$ as a white solid; m.p. $130.1{ }^{\circ} \mathrm{C}\left(\right.$ lit. $\left.^{18} 129-130{ }^{\circ} \mathrm{C}\right) ; v_{\max } / \mathrm{cm}^{-}$ $13299(\mathrm{NH}), 1665(\mathrm{C}=\mathrm{O})$.

Attempted synthesis of ß-chloroisovaleric acid. ${ }^{8}$ A solution of 3,3-dimethylacrylic acid (75 g, $0.75 \mathrm{~mol})$ in anhydrous ether $(380 \mathrm{~mL})$ at $0{ }^{\circ} \mathrm{C}$ was saturated with anhydrous $\mathrm{HCl}$ gas. The flask was tightly sealed and stood at ambient for 6 days. The solution was concentrated under reduced pressure and the residue recrystallised from light petroleum to yield solely 3,3-dimethylacrylic, essentially quantitatively.

Attempted synthesis of methyl ß-chloroisovalerate. ${ }^{9}$ To a solution of isovaleric acid (50 g, $0.49 \mathrm{~mol})$ in 1,2-dichloroethane (75.05 g) was added sulfuryl chloride (66.12 $\mathrm{g}, 0.5 \mathrm{~mol})$ and benzoyl peroxide $(75 \%, 0.52 \mathrm{~g}, 1.5 \mathrm{mmol})$ and the mixture stirred at reflux for $5 \mathrm{~h}$ until the evolution of gas ceased. After cooling, methanol $(300 \mathrm{~mL})$ and conc. $\mathrm{H}_{2} \mathrm{SO}_{4}(10 \mathrm{~mL})$ were added and the solution concentrated to $300 \mathrm{~mL}$ by distillation. To the residual solution was added methanol $(50 \mathrm{~mL})$ and the solution stirred at reflux for $2 \mathrm{~h}$. After cooling, the solution was concentrated under reduced pressure, poured into water $(50 \mathrm{~mL})$ and extracted with ether $(3 \mathrm{x}$ $50 \mathrm{~mL})$. The extracts were washed with water $(50 \mathrm{~mL})$, dried $\left(\mathrm{MgSO}_{4}\right)$ and concentrated under reduced pressure. Distillation of the residue yielded methyl $\mathrm{g}$-chloroisovalerate $(13.30 \mathrm{~g}, 16 \%)$ as a colourless oil; bp $74-88{ }^{\circ} \mathrm{C} / 20 \mathrm{mmHg} ; v_{\max } / \mathrm{cm}^{-1} 1739(\mathrm{C}=\mathrm{O}) ;{ }^{1} \mathrm{HNMR} \delta 1.04(3 \mathrm{H}, \mathrm{d}, J=$ $\left.6.60 \mathrm{~Hz}, \mathrm{CH}_{3}\right), 2.24(1 \mathrm{H}, \mathrm{dd}, J=15.17,7.26 \mathrm{~Hz}, \mathrm{CH}), 2.30-2.48(1 \mathrm{H}, \mathrm{m}, \mathrm{CH}), 2.55(1 \mathrm{H}, \mathrm{dd}, J=$ 15.17,7.25 Hz, CH), 3.47-3.58 (2H, m, $\left.\mathrm{CH}_{2}\right), 3.69\left(3 \mathrm{H}, \mathrm{s}, \mathrm{CH}_{3}\right)$.

3-(2-Carboxy-4-nitroanilino)-3-methylbutyric acid. To a solution of $\beta$-aminoisovaleric acid (0.75 g, $6 \mathrm{mmol})$, in dry DMF (15 mL) was added 2-fluoro-5-nitrobenzoic acid (1.11 g, $6 \mathrm{mmol})$, anhydrous $\mathrm{K}_{2} \mathrm{CO}_{3}(1.00 \mathrm{~g}, 7 \mathrm{mmol})$ and the mixture stirred at $95{ }^{\circ} \mathrm{C}$ for $6 \mathrm{~h}$. The mixture was concentrated under reduced pressure and the residue acidified to $\mathrm{pH} 3-5$ with aqueous $\mathrm{HCl}(2 \mathrm{M})$ to yield the title compound as a yellow solid (1.70 g, 96\%) mp $194{ }^{\circ} \mathrm{C}$; HRMS (EI+) calc for $\mathrm{C}_{12} \mathrm{H}_{14} \mathrm{~N}_{2} \mathrm{O}_{6}(\mathrm{M})$ 282.085. Found 282.085; $v_{\max } / \mathrm{cm}^{-1} 3365(\mathrm{NH}), 1722(\mathrm{C}=\mathrm{O}), 1537\left(\mathrm{NO}_{2}\right)$ and $1326\left(\mathrm{NO}_{2}\right) ;{ }^{1} \mathrm{HNMR}\left(\mathrm{d}_{6} \mathrm{DMSO}\right) \delta 1.29\left(6 \mathrm{H}, \mathrm{s}, 2 \times \mathrm{CH}_{3}\right), 2.31\left(2 \mathrm{H}, \mathrm{s}, \mathrm{CH}_{2}\right), 3.17$ (br s, NH), $6.77(1 \mathrm{H}, \mathrm{d}, J=9.24 \mathrm{~Hz}, \mathrm{ArH}), 7.85(1 \mathrm{H}, \mathrm{dd}, J=9.24,2.64 \mathrm{~Hz}, \mathrm{ArH}), 8.65$ (1H. d, $J=2.64 \mathrm{~Hz}$ ArH), 11.23 (1H, s, OH).

Methyl 3-(2-(methoxycarbonyl)-4-nitroanilino)-3-methylbutyrate. To a solution of 3-(2carboxy-4-nitroanilino)-3-methylbutyric acid $(1.80 \mathrm{~g}, 6.38 \mathrm{mmol})$ in methanol $(10 \mathrm{~mL})$ was added an ethereal solution of diazomethane until an excess was detected. The diazomethane was allowed to evaporate and the residue recrystallised from methanol to yield the title product $\left(1.60 \mathrm{~g}, 80 \%\right.$ ) as a yellow solid; mp 116.8- $117.2{ }^{\circ} \mathrm{C}$; HRMS (EI+) calc for $\mathrm{C}_{14} \mathrm{H}_{18} \mathrm{~N}_{2} \mathrm{O}_{6}$ 
(M) 310.116. Found $\mathrm{m}^{+} 310.115 ; v_{\max } / \mathrm{cm}^{-1} 3299(\mathrm{NH}), 1723(\mathrm{C}=\mathrm{O})$ and $1324\left(\mathrm{NO}_{2}\right) ;{ }^{1} \mathrm{HNMR} \delta$ $1.60\left(6 \mathrm{H}, \mathrm{s}, 2 \mathrm{x} \mathrm{CH}_{3}\right), 2.81\left(2 \mathrm{H}, \mathrm{s}, \mathrm{CH}_{2}\right), 3.66\left(3 \mathrm{H}, \mathrm{s}, \mathrm{CH}_{3}\right), 3.92\left(3 \mathrm{H}, \mathrm{s}, \mathrm{CH}_{3}\right), 6.92(1 \mathrm{H}, \mathrm{d}, J=$ $9.89 \mathrm{~Hz}, \mathrm{ArH}), 8.19$ (1H, dd, $J=9.90,3.30 \mathrm{~Hz}, \mathrm{ArH}), 8.90$ (1H. d, $J=3.29 \mathrm{~Hz} \mathrm{ArH}), 9.07(1 \mathrm{H}$, $\mathrm{s} \mathrm{NH})$. The peak at 9.07 collapses with $\mathrm{D}_{2} \mathrm{O}$.

Attempted Claisen condensation of methyl 3-(2-(methoxycarbonyl)-4-nitroanilino)-3methylbutyrate. To dry ethanol $(18 \mathrm{~mL})$ was added sodium $(0.05 \mathrm{~g}, 2 \mathrm{mmol})$ and the mixture stirred until the sodium dissolved. The solution was heated to reflux and a hot solution of methyl 3-(2-(methoxycarbonyl)-4-nitroanilino)-3-methylbutyrate $(0.5 \mathrm{~g}, 1.6 \mathrm{mmol})$ in dry ethanol $(20 \mathrm{~mL})$ was added over $90 \mathrm{~min}$. The reaction mixture was stirred at reflux for $20 \mathrm{~h}$. After cooling, the mixture was poured into ice-water $(30 \mathrm{~mL})$, acidified with conc. $\mathrm{HCl}$ and continuously extracted with chloroform. The organic layer was dried $\left(\mathrm{MgSO}_{4}\right)$ and concentrated under reduced pressure. Flash column chromatography with methanol-ethyl acetate- $0.1 \%$ aqueous ammonium hydroxide (20:80:0.1) furnished an orange oil, which upon acidification with aqueous $\mathrm{HCl}(2 \mathrm{M})$ yielded 3-(2-carboxy-4-nitroanilino)-3-methylbutyric acid(0.30 g, $66 \%$ ), as a yellow solid; mp $189^{\circ} \mathrm{C}$.

1,2-Dihydro-2,2-dimethylquinoline. ${ }^{19}$ To a solution of the 3-acetoxy-3-methylbut-1-yne (12.00 $\mathrm{g})$ in dry THF $(100 \mathrm{~mL})$ was added an aniline $(0.77 \mathrm{~mol})$ over $5 \mathrm{~min}$ and then $\mathrm{CuCl}(0.78 \mathrm{~g}$, $7 \mathrm{mmol})$ and the mixture stirred at reflux for $3 \mathrm{~h}$. Further $\mathrm{CuCl}(0.78 \mathrm{~g}, 7 \mathrm{mmol})$ was added and the mixture stirred at reflux for another $1 \mathrm{~h}$. The mixture was cooled, filtered and the filtrate concentrated under vacuum. The residue was poured into saturated aqueous $\mathrm{NH}_{4} \mathrm{Cl}(200 \mathrm{~mL})$, and extracted with ethyl acetate $(3 \times 250 \mathrm{~mL})$. The extracts were washed with saturated aqueous $\mathrm{NH}_{4} \mathrm{Cl}(1 \times 200 \mathrm{~mL})$ and then brine $(1 \times 200 \mathrm{~mL})$ and dried $\left(\mathrm{MgSO}_{4}\right)$ and concentrated under reduced pressure. Distillation of the residue yielded the title product as a pale yellow oil (7.57 $\mathrm{g}$, $62 \%$;); bp $80{ }^{\circ} \mathrm{C} / 0.1 \mathrm{mmHg}$ (lit. ${ }^{19} 50-51{ }^{\circ} \mathrm{C} / 0.07 \mathrm{mmHg}$ ); $v_{\max } / \mathrm{cm}^{-1} 3376(\mathrm{NH}) ;{ }^{1} \mathrm{HNMR} \delta 1.28$ $\left(6 \mathrm{H}, \mathrm{s}, 2 \times \mathrm{CH}_{3}\right), 3.56(1 \mathrm{H}$, br s, NH), $5.44(1 \mathrm{H}, \mathrm{d}, J=9.23 \mathrm{~Hz}, \mathrm{ArH}), 6.24(1 \mathrm{H}, \mathrm{d}, J=9.89 \mathrm{~Hz}$, ArH), $6.38(1 \mathrm{H}, \mathrm{d}, J=7.91 \mathrm{~Hz}, \operatorname{ArH}), 6.56(1 \mathrm{H}, \mathrm{t}, J=7.26 \mathrm{~Hz}, \operatorname{ArH}$ 's $), 6.85(1 \mathrm{H}, \mathrm{d}, J=7.26 \mathrm{~Hz}$, ArH), $6.88(1 \mathrm{H}, \mathrm{t}, J=7.92 \mathrm{~Hz}, \mathrm{ArH})$.

1,2-Dihydro-2,2,8-trimethylquinoline. The above procedure was repeated substituting 2methylaniline for aniline and gave the title product as a pale yellow oil $(4.8 \mathrm{~g}, 36 \%)$; b.p. $70{ }^{\circ} \mathrm{C} /$ $0.1 \mathrm{mmHg}$ (lit. ${ }^{19} 103{ }^{\circ} \mathrm{C} / 4 \mathrm{mmHg}$ ); $v_{\max } / \mathrm{cm}^{-1} 3408(\mathrm{NH}) ;{ }^{1} \mathrm{HNMR} \delta 1.41\left(6 \mathrm{H}, \mathrm{s}, 2 \times \mathrm{CH}_{3}\right), 2.22$ $\left(3 \mathrm{H}, \mathrm{s}, \mathrm{CH}_{3}\right), 3.59(2.5 \mathrm{H}, \mathrm{br} \mathrm{s}, \mathrm{NH}), 5.55(1 \mathrm{H}, \mathrm{d}, J=9.89 \mathrm{~Hz}, \mathrm{ArH}), 6.36(1 \mathrm{H}, \mathrm{d}, J=9.90 \mathrm{~Hz}$, ArH), $6.61(1 \mathrm{H}, \mathrm{td}, J=7.92,7.25 \mathrm{~Hz}, \operatorname{ArH}) ; 6.87(1 \mathrm{H}, \mathrm{d}, J=7.92 \mathrm{~Hz}, \operatorname{ArH}), 6.96(1 \mathrm{H}, \mathrm{d}, J=$ $7.26 \mathrm{~Hz}, \mathrm{ArH})$.

1-t-Butoxycarbonyl-1,2-dihydro-2,2-dimethylquinoline ${ }^{11}$ and 1-t-butoxy-carbonyl-1,2dihydro-2,2,8-trimethylquinoline. To a solution of 1,2-dihydro-2,2-dimethylquinoline $(15 \mathrm{mmol})$ in anhydrous ether $(40 \mathrm{~mL})$ at $-78{ }^{\circ} \mathrm{C}$ was added a solution of $n$-butyllithium $(2.5 \mathrm{M}$, $9 \mathrm{~mL}, 22 \mathrm{mmol}$ ) over $5 \mathrm{~min}$ ensuring that the temperature did not exceed $-65{ }^{\circ} \mathrm{C}$. The reaction mixture was stirred at $-65{ }^{\circ} \mathrm{C}$ for $10 \mathrm{~min}$ and then a solution of di-tert-butyl dicarbonate $(4.50 \mathrm{~g}$, $20 \mathrm{mmol})$ in anhydrous ether $(10 \mathrm{~mL})$ was added over $5 \mathrm{~min}$. The reaction mixture was stirred for $2 \mathrm{~h}$, during which time the mixture was allowed to warm to ambient. The solution was poured 
into aqueous $\mathrm{Na}_{2} \mathrm{SO}_{4}(1 \mathrm{M}, 10 \mathrm{~mL})$ and extracted with ethyl acetate $(2 \times 50 \mathrm{~mL})$. The extracts were washed with brine $(75 \mathrm{~mL})$, dried $\left(\mathrm{Na}_{2} \mathrm{SO}_{4}\right)$ and concentrated under reduced pressure to yield 1-t-butoxycarbonyl-1,2-dihydro-2,2-dimethylquinoline admixed with the unprotected dihydroquinoline $(3: 2)$ ratio, as a pale yellow oil $(3.41 \mathrm{~g}) ; v_{\max } / \mathrm{cm}^{-1} 1710(\mathrm{C}=\mathrm{O})$; $\left(\right.$ lit. $^{11}{ }^{1} \mathrm{HNMR}$ d $1.52\left(9 \mathrm{H}, \mathrm{s}, \mathrm{CH}_{3}\right), 1.53\left(6 \mathrm{H}, \mathrm{s}, 2 \mathrm{x} \mathrm{CH}_{3}\right), 5.58(1 \mathrm{H}, \mathrm{d}, J=9.23 \mathrm{~Hz}, \mathrm{ArH}), 6.27(1 \mathrm{H}, \mathrm{d}, J=9.24$ $\mathrm{Hz} \mathrm{ArH}), 6.90-6.95$ (2H, m 2 x ArH), 7.08 (1H, m, ArH), 7.17 (1H, d, J=7.91 Hz, ArH).

The reaction was repeated using 1,2-dihydro-2,2,8-trimethylquinoline to give 1-tbutoxycarbonyl-1,2-dihydro-2,2,8-trimethylquinoline as a 1:1 mixture of unprotected and protected dihydroquinolines as a pale yellow oil $(4.30 \mathrm{~g}) ; v_{\max } / \mathrm{cm}^{-1} 1714(\mathrm{C}=\mathrm{O}) ;{ }^{1} \mathrm{HNMR} \delta 1.40$ (9H, s, $\mathrm{CH}_{3}$ 's), 1.38 (6H, s, $\mathrm{CH}_{3}$ 's), 5.84 (1H, d, J=9.23 Hz, ArH's), 7.03 (2H, d, J = 9.24 Hz, 2 x ArH), 6.85-6.92 (1H, m, ArH), 7.01-7.09 (2H, m, 2 x ArH).

\section{General method for the hydroboration of protected quinolines using borane. THF complex $^{11}$}

To a solution of the Boc-protected quinoline $(5 \mathrm{mmol})$ in dry THF $(10 \mathrm{~mL})$ at room temperature was added a solution of $\mathrm{BH}_{3}$. THF $(1.0 \mathrm{M}, 15 \mathrm{~mL}, 15 \mathrm{mmol})$. The reaction mixture was stirred for $24 \mathrm{~h}$ and then a solution of aqueous $\mathrm{KOH}(10 \%, 0.5 \mathrm{~mL})$ was added, followed by hydrogen peroxide $(27 \%, 1.3 \mathrm{~mL}, 10 \mathrm{mmol})$. The reaction mixture was stirred for $1 \mathrm{~h}$ when solution was poured into water $(10 \mathrm{~mL})$ and extracted with ethyl acetate $(2 \times 50 \mathrm{~mL})$. The extracts were washed with brine $(2 \times 50 \mathrm{~mL})$, dried $\left(\mathrm{Na}_{2} \mathrm{SO}_{4}\right)$ and concentrated under reduced pressure.

From 1-t-butoxycarbonyl-1,2-dihydro-2,2-dimethylquinoline was obtained 1-t-butoxycarbonyl1,2,3,4-tetrahydro-4-hydroxy-2,2-dimethylquinoline as white needles $(0.60 \mathrm{~g}, 43 \%)$ by chromatography with light petroleum - ethyl acetate $(9: 1)$ as the initial eluent followed by ethyl acetate, which yielded the product as a mixture of the 3- and 4-hydroxy isomers. The 3-isomer was removed by washing with hexane $(20 \mathrm{~mL})$. ; 1-t-butoxycarbonyl-1,2,3,4-tetrahydro-4hydroxy-2,2-dimethylquinoline had m.p. $147.5-148.7{ }^{\circ} \mathrm{C} ; v_{\max } / \mathrm{cm}^{-1} 3426(\mathrm{OH}), 1660(\mathrm{C}=\mathrm{O}) ; \delta_{\mathrm{H}}$ (d $\left.\mathrm{d}_{6} \mathrm{DMSO}\right) 1.43\left(9 \mathrm{H}, \mathrm{s}, 3 \times \mathrm{CH}_{3}\right), 1.45\left(6 \mathrm{H}, \mathrm{s}, 2 \times \mathrm{CH}_{3}\right), 2.05\left(1 \mathrm{H}, \mathrm{dd}, J 11.88, J 3.95, \mathrm{CH}_{2}\right)$, 4.52-4.56 (1H, m, CH), 5.40 (1H, d, J 5.28, ArH).

From 1-t-butoxycarbonyl-1,2-dihydro-2,2,8-trimethylquinoline was obtained with the above work-up 1-t-butoxycarbonyl-1,2,3,4-tetrahydro-4-hydroxy-2,2,8-trimethylquinoline as white needles (0.20 g, 14.3\%); mp 142.8-143 ${ }^{\circ} \mathrm{C}$; HRMS (EI+) Calc for $\mathrm{C}_{17} \mathrm{H}_{25} \mathrm{NO}_{3}$. (M) 291.183. Found 291.182; $v_{\max } / \mathrm{cm}^{-1} 3414(\mathrm{OH}), 1666(\mathrm{C}=\mathrm{O}) ;{ }^{1} \mathrm{HNMR}\left(\mathrm{d}_{6} \mathrm{DMSO}\right) \delta 1.30\left(3 \mathrm{H}, \mathrm{s}, \mathrm{CH}_{3}\right)$, $1.42\left(9 \mathrm{H}, \mathrm{s}, 3 \times \mathrm{CH}_{3}\right), 1.66\left(3 \mathrm{H}, \mathrm{s}, \mathrm{CH}_{3}\right), 2.06\left(3 \mathrm{H}, \mathrm{s}, \mathrm{CH}_{3}\right), 2.10(1 \mathrm{H}, \mathrm{dd}, J=12.2,3.63 \mathrm{~Hz}$, $\mathrm{CH})$; 4.50-4.57 (1H, m, CH), $5.37(1 \mathrm{H}, \mathrm{d}, J=5.28 \mathrm{~Hz}, \mathrm{CH}), 7.00(2 \mathrm{H}, \mathrm{d}, J=5.28 \mathrm{~Hz}, 2 \mathrm{x} \mathrm{ArH})$, $7.22(1 \mathrm{H}, \mathrm{t}, J=5.28 \mathrm{~Hz})$.

1-t-butoxycarbonyl-1,2,3,4-tetrahydro-2,2-dimethylquinolin-4-one ${ }^{11}$ and 1-t-butoxycarbonyl1,2,3,4-tetrahydro-2,2,8-trimethylquinolin-4-one. To a solution of the above alcohols (2 mmol) in dry dichloromethane $(5 \mathrm{~mL})$ was added pyridinium chlorochromate $(0.60 \mathrm{~g}, 3 \mathrm{mmol})$ and the reaction mixture was stirred for $3 \mathrm{~h}$ when it was concentrated to dryness under reduced pressure 
and the residue purified by flash column chromatography using light petroleum - ethyl acetate (9:1) as the eluent to yield the following products:

From 1-t-butoxycarbonyl-1,2,3,4-tetrahydro-4-hydroxy-2,2-dimethylquinoline was obtained 1-tbutoxycarbonyl-1,2,3,4-tetrahydro-2,2-dimethylquinolin-4-one as a colourless solid (0.436 $\mathrm{g}$, 88\%); m.p. 68.5- $69.8{ }^{\circ} \mathrm{C} ; v_{\max } / \mathrm{cm}^{-1} 1713(\mathrm{C}=\mathrm{O})$ and $1690(\mathrm{C}=\mathrm{O}) ;{ }^{1} \mathrm{HNMR} \delta 1.50\left(6 \mathrm{H}, \mathrm{s}, \mathrm{CH}_{3}\right.$ 's $)$, $1.56\left(9 \mathrm{H}, \mathrm{s}, \mathrm{CH}_{3}\right.$ 's), $2.73\left(2 \mathrm{H}, \mathrm{s}, \mathrm{CH}_{2}\right), 7.02(1 \mathrm{H}, \mathrm{ddd}, J=7.94,1.32 \mathrm{~Hz}, \mathrm{ArH}$ 's), 7.30 (1H, t, $J=$ $7.91 \mathrm{~Hz}$, ArH's), 7.43 (1H, ddd, $\left.J=6.60,1.32 \mathrm{~Hz}, \mathrm{ArH}^{\prime} \mathrm{s}\right), 7.93(1 \mathrm{H}, \mathrm{dd}, J=7.92,1.98 \mathrm{~Hz}$, ArH's).

From 1-t-butoxycarbonyl-1,2,3,4-tetrahydro-4-hydroxy-2,2,8-trimethylquinoline was obtained 1t-butoxycarbonyl-1,2,3,4-tetrahydro-2,2,8-trimethylquinolin-4-one as a colourless solid $(0.487 \mathrm{~g}$, 91\%); mp 87 - 87.2 ${ }^{\circ} \mathrm{C}$; HRMS (EI+) Calc for $\mathrm{C}_{17} \mathrm{H}_{23} \mathrm{NO}_{3}$. (M) 289.167. Found 289.167; $v$ $\max / \mathrm{cm}^{1} 1707(\mathrm{C}=\mathrm{O})$ and $1683(\mathrm{C}=\mathrm{O}) ;{ }^{1} \mathrm{HNMR} \delta 1.37\left(9 \mathrm{H}, \mathrm{s}, 3 \times \mathrm{CH}_{3}\right), 1.49\left(6 \mathrm{H}, \mathrm{s}, 2 \times \mathrm{CH}_{3}\right)$, $2.28\left(3 \mathrm{H}, \mathrm{s}, \mathrm{CH}_{3}\right), 2.80\left(2 \mathrm{H}, \mathrm{s}, \mathrm{CH}_{2}\right), 7.18(1 \mathrm{H}, \mathrm{t}, J=7.59 \mathrm{~Hz}, \mathrm{ArH}), 7.37-7.40(1 \mathrm{H}, \mathrm{m}, \operatorname{ArH})$, $7.77(1 \mathrm{H}, \mathrm{m} \mathrm{ArH})$.

1,2,3,4-Tetrahydro-2,2-dimethylquinolin-4-one ${ }^{11}$ and 1,2,3,4-tetrahydro-2,2,8-trimethylquinolin-4one. To a solution of the above protected quinolines $(1.09 \mathrm{mmol})$ in dry dichloromethane $(2 \mathrm{~mL})$ at $0{ }^{\circ} \mathrm{C}$ was added trifluoroacetic acid $(1.2 \mathrm{~mL})$ over $3 \mathrm{~min}$. The reaction mixture was stirred for $3 \mathrm{~h}$ during which time the mixture warmed to room temperature. The solution was concentrated under reduced pressure, toluene $(10 \mathrm{~mL})$ added and the solution again concentrated under reduced pressure. The residue was dissolved in dichloromethane $(30 \mathrm{~mL})$ and washed with saturated aqueous $\mathrm{NaHCO}_{3}(20 \mathrm{~mL})$. The aqueous phase was extracted with dichloromethane $(20 \mathrm{~mL})$. The organic extracts were dried $\left(\mathrm{Na}_{2} \mathrm{SO}_{4}\right)$ and concentrated under reduced pressure to yield the title products as follows:

1,2,3,4-Tetrahydro-2,2-dimethylquinolin-4-one as yellow needles (0.18 g, 94\%); m.p. 82-83 ${ }^{\circ} \mathrm{C}\left(\right.$ lit. $\left.{ }^{20} 85{ }^{\circ} \mathrm{C}\right) ; v_{\max } / \mathrm{cm}^{-1} 3326(\mathrm{NH}), 1659(\mathrm{C}=\mathrm{O}) ;{ }^{1} \mathrm{HNMR} d 1.33\left(6 \mathrm{H}, \mathrm{s}, 2 \times \mathrm{CH}_{3}\right), 2.59(2 \mathrm{H}$, s, $\left.\mathrm{CH}_{2}\right), 4.13(1 \mathrm{H}$, br s, NH), $6.58(1 \mathrm{H}, \mathrm{d}, J=1.98 \mathrm{~Hz}, \mathrm{ArH}), 6.63(1 \mathrm{H}, \mathrm{t}, J=7.91 \mathrm{~Hz}, \mathrm{ArH})$, 7.25-7.32 (2H, m, 2 x ArH), $7.80(1 \mathrm{H}, \delta J=7.92 \mathrm{~Hz}, \mathrm{ArH})$.

1,2,3,4-Tetrahydro-2,2,8-trimethyl-quinolin-4-one as yellow needles from tetrachloroethylene (0.19 g, 96\%); mp 135.6-135.8 ${ }^{\circ} \mathrm{C}$; HRMS (EI+) Calc for $\mathrm{C}_{12} \mathrm{H}_{15} \mathrm{NO}(\mathrm{M})$ 189.115. Found 189.114; $v_{\max } / \mathrm{cm}^{-1} 3372(\mathrm{NH}), 1659(\mathrm{C}=\mathrm{O}) ;{ }^{1} \mathrm{HNMR} \delta 1.35\left(6 \mathrm{H}, \mathrm{s}, 2 \times \mathrm{CH}_{3}\right), 2.14\left(3 \mathrm{H}, \mathrm{s}, \mathrm{CH}_{3}\right)$, $2.60\left(2 \mathrm{H}, \mathrm{s}, \mathrm{CH}_{2}\right), 4.01(1 \mathrm{H}, \mathrm{br} \mathrm{s}, \mathrm{NH}), 6.64(1 \mathrm{H}, \mathrm{t}, J=7.59 \mathrm{~Hz}, \mathrm{ArH}), 7.23(1 \mathrm{H}, \mathrm{d}, J=7.25 \mathrm{~Hz}$, ArH), $7.74(1 \mathrm{H}, \mathrm{d}, J=7.91 \mathrm{~Hz}, \mathrm{ArH})$.

\section{Acknowledgements}

We thank A H Marks and the EPSRC for a CASE award to I.P.C. which made this work possible. 


\section{References}

1. Shlyapintokh, V. Ya.; Bystritzkaya, E. V.; Shapiro, A. B.; Smirnov, L. N.; Rozantsev, E. G. Izv. Akad. Nauk. SSSR. Ser Khim. 1973, 7, 1915.

2. Ivanov, Yu. A.; Kokorin, A. I.; Shapiro, A. B.; Rozantsev, E. G. Izv. Akad. Nauk. SSSR Ser. Khim. (Engl Transl). 1976, 10, 2217.

3. Barmettler P.; Hansen, H. J. Helv. Chim. Acta. 1990, 73, 1515.

4. Eberson, L.; Cardellini, L.; Greci, L.; Poloni, M. Gazz. Chim. Ital. 1988, 118, 35.

5. McKillop A.; Kemp, D. Tetrahedron 1989, 45, 3299.

6. Bellassoued-Fargeau M-C.; Graffe, B.; Sacquet, M-C.; Maitte, P. J. Heterocycl. Chem. 1985, 22, 713.

7. Nagao, Y.; Kumagai, T.; Tamai, S.; Matsunaga, Abe, H. T.; Inoue, Y. Heterocycles 1996, $42,849$.

8. Eliel E. L;.Traxler, J. T. J. Am. Chem. Soc. 1956, 78, 4049.

9. Smith, L. I..; Spillane, L. J. J. Am. Chem. Soc. 1943, 65, 282.

10. Kharasch M. S.; Brown, H. C. J. Am. Chem. Soc.1940, 62, 925.

11. Hamann, L.G.; Higuchi, R. I.; Zhi, L.; Edwards, J. P.; Wang, X.-N.; Marschke, K. B.; Kong, J. W.; Farmer L. J.; Jones, T. K. J. Med. Chem. 1998, 41, 623.

12. Banerjee S.; Trivedi, G. K. Tetrahedron 1992, 48, 9939.

13. Hennion, G. F.; Boisselle, A. P. J. Org. Chem.1961, 26, 725.

14. Kaneko, C. Naito, T.; Hashiba, M. Chem. Pharm. Bull. 1979, 27, 1813.

15. Slimmer, M. D. Chem. Ber. 1902, 35, 400.

16. Bil, M. Chem. Ind. (London) 1970, 892.

17. Taylor, E. C.; Lamattina J. U.; Tseng, Chi-Ping J. Org. Chem. 1982, 47, 2043.

18. Nagata W.; Kamata S. J. Chem. Soc. (C) 1970, 540.

19. Dillard, R. D.; Pavey D. E.; Benslay, D. N. J. Med. Chem. 1973, 16, 251.

20. Hennion G. F.; Hanzel, R. S. J. Am. Chem. Soc. 1960, 82, 4908. 